\title{
Individual Differences Considering Students' Learning Styles
}

\author{
Dr. Johana Myftiu \\ Psychology Department, Aleksandër Xhuvani University, Albania \\ johanamyftiu@hotmail.com
}

\section{Doi:10.5901/mjss.2015.v6n3s1p214}

\begin{abstract}
This paper aims at the importance of knowing the learning styles of the students on the part of the teachers to build on their teaching methodology according to them. The paper also offers overall information on learning styles, their categorization and suggests helpful techniques for teachers to adopt their teaching style to the students' learning style. An emphasis is put on the idea that there exist no strict rules and rigorous distinctions between them or completely pure styles. Every student is unique, thus their learning styles are different. Students with a learning style preference will learn more effectively if the learning process is guided according to their preferred style. Despite the variety of terms used for naming the learning styles as identified during the research work, it is crucial that teachers, instructors and even the learners value these styles as one of the factors that affect successful teaching process. The study is carried out through a detailed study of the existing theoretical literature on the topic and on the interviews and classroom observations conducted with the students on the same issue. Success in our life style much depends on the learning styles, which are very important to be known by educators. The paper comes to the conclusion that individual differences on learning styles affect a lot the teaching methodology of the teachers.
\end{abstract}

Keywords: learning styles, individual preferences, sutability, teachers, students.

\section{Introduction}

People think and learn in different ways, but some of us learn better in some ways than others. Noticing these individual differences, educators and researchers have been interested in finding appropriate ways to match their teaching styles to students' learning styles. Through this paper the researcher tries to give a deep theoretical background on learning styles and recommends some helpful techniques for teachers to adopt their teaching style to the students' learning styles. An emphasis is put on the idea that there exist no strict rules and rigorous distinctions between them or completely pure styles. One of the hypothesis is that every student is unique, thus, their learning styles are different. Despite the variety of terms used for naming the learning styles as identified during the research work, it is crucial that teachers, instructors and even the learners value these styles as one of the factors that affect successful teaching process. The main objective of this paper is that individual differences of students concerning learning styles affect a lot the teaching skills.

Having in mind the aims and objective of this study, this research tries to provide answers to research questions considering the importance of students' differences in the learning process, their effect learning styles on teaching methodologies.

The study tries to come to the conclusion that students with a learning style preference will learn more effectively if the learning process is guided according to their preferred style. Success in our life style much depends on the learning styles, which are very important to be known by educators. The paper comes to the conclusion that individual differences on learning styles affect a lot the teaching methodology of the teachers.

\section{Literature Review, Theoretical Background of the Issue}

The study is carried out through a detailed study of the existing theoretical literature on the topic, studying mainly what the outstanding scholars of the field have written about students' learning styles, their differences and preferences.

\subsection{The definition of the terms}

According to Berry (1976), one of the factors affecting the learning style is cultural difference. In every group, different learning characteristics will always appear: different cultural groups might emphasize a cognitive style against another (Cited by More et al., 1987). 
The nuance of the term "style" varies considerably amongst scholars. For some of them, "style" refers to a psychological characteristic (cognitive style) that involves the intellectual, perceptive and intrapersonal functioning (Keefe, 1979). Other scholars consider "style" as "the best" or "most favorite" approach in which a student may learn.

A learning style is a consistent approach of responding to stimuli and using them within the learning context. It is an approach, through which a person perceives, conceptualizes, organizes and remembers information (Pontecorvo, 1994). People develop their own personal style, based on their culture, genetics, previous experience and respective social environment.

Scholars highlight the student's behavior in defining the learning style. Kocinski (1984) defines the learning style as favorite learning approach and the best approach through which a person best learns. Considering the learning style notion as a major component of Jung psychology type theory, he emphasizes the idea that an individual's learning styles are reflections of personality types. (Cited by Heineman,1995)

Keefe (1979) suggests that the learning styles are cognitive, affective, and psychological behaviors that serve as relatively stable indicators of how students perceive, get attached and respond to the learning circumstances (Cited by Verster, 2007).

Frequently in psychology literature, the learning styles are also examined according to the perspective of liaison to intelligence, especially Gardner's multiple-intelligence.

Regardless the various perspectives and attempts to define this concept, the learning styles, therefore, can simply be perceived as different approaches or ways to learn.

\subsection{Theories on learning styles}

Several theories, outlooks and categorizations are existent about them and their different types are also recognized. This variety of outlooks is exactly one of the indicators that explains the variety and diversity of learning individuals.

\subsubsection{Some models and categorizations that we find helpful in discerning learning styles}

Academics offer us a number of models, categories and dimensions on learning styles. Here we mention the model widely used by Kolb and his associates; the MBTI (Myers Briggs Type Indicator) model; the Herrman model based on brain dominance, etc.

The Kolb learning theory (1974), emphasizes four evident learning styles (or preferences) that are based upon four stages of learning cycle. This theory, in fact, offers a model for understanding different learning styles in people, and in the meantime it explains the experimental learning cycle that we follow.

According to Kolb (1974), this process (ideally and not always), presents a cycle or spiral where the learner "touches upon" all bases: so we have a cycle that includes experience, reflection, thinking and action (Cited by Wall, 2004). In this classification, the learner has a preference for: 1) concrete experience or abstract conceptualization (how information is attained) and 2) active experimenting or reflective observation (how information is internalized). Based on this scheme, four learner types are distinguished (Kolb, 1974).

- Type 1 ( diverging) - concrete-reflective

- Type 2 (assimilating) - abstract-reflective

- Type 3 (converging) - abstract-active

- $\quad$ Type 4 (accommodating) - concrete - active

So, we choose an approach to "grasp the experience" and an approach to "transform the experience".

Traditional teaching in general carries out a formal presentation of materials suitable for type 2 . In order to be suitable for all types of students, a teacher should explain the connection to every new topic (Type 1), present basic information and methods connected to the topic (Type 2), bring about opportunities to practice (Type 3), and encourage exploration to exercise (Type 4).

One of the most popular models today is also the VARK (Visual, Auditory, Read/Write, and Kinesthetic) style. This model uses three sensorial receptors: Vision, Auditory and Kinesthetic (movement), which define the dominant learning style. Normally, one of them is more dominant, but it might not always be the same for a variety of assignment types. Providing us with the Index of Learning Styles (ILS), Felder \& Soloman, (1980, 2002), describe a number of their characteristics of great importance to be known by teachers and educators. So, we have this classification (Cited by Fleming, 2014):

- Sensorial students, that prefer concrete, practical information, interested in intuitive facts or students that 
prefer theoretical and conceptual information.

- Visual students that prefer information to be presented in graphics, diagrams, tables, etc., or verbal students that prefer written or heard information, dialogue and discussion, etc.

- Inductive students that prefer information to be presented from specific to general or deductive students that prefer information to be presented from general to specific.

- Active students that learn while trying, manipulating objects and working in group or reflective students that prefer to learn by analyzing and working on their own.

- Sequential students that acquire information being presented in a linear manner, with small steps, or global students that prefer to acquire information as a whole and then move on to details.

Another model, of Meyers-Briggs presents four personality dimensions: introvert and extravert, thinking and feeling.

Similar to the "reflective thinkers" mentioned above, the introverts prefer to focus on internal thoughts and feelings and might prefer a calm surrounding to learn; they listen more than they speak in class.

Similar to "active students", extraverts more often prefer to speak loudly and they feel well while cooperating with others. These students may prefer cooperative learning while thinking and discussing in a similar environment.

Thinking students like to use impersonal objectives for taking decisions and having opinions. These students may feel good in personal conflicts with other students: they prefer concrete language and work directly with data.

Sensitive students tend to focus on personal emotions and values when taking decisions and having opinions, they appreciate group harmony.

\section{Methodology of the Study}

The methodology used for carrying out this study is mainly the theoretical type of research, concentrated on the detailed study of the existing literature, what the outstanding scholars have said about learning styles, categorization and their effect and influence on the teaching methodologies. There have been used other research techniques to apply these theories in the Albanian context, as observations in the real classrooms, interviews with students and teachers, etc.

In general, the most preferred research techniques used in this study on learning styles, are of two types: the questionnaires and the analysis of the answers of the students after they have learned a certain material. In this case the answers are considered as indicators of the strategies used while learning.

In order to identify what really happens as far as learning is concerned, a questionnaire was built with open and closed questions. The purpose was to gather data and information about knowing and using learning styles in classroom context. It also aimed at understanding the strategies used by the teachers to match their teaching style to students' learning styles. Some of the questions in the questionnaire were based on VARK Model, and particularly on senses: visual, auditory and kinesthetic learning styles. There were 60 participants, teachers and in three 9 -year schools.

\section{Findings and Results}

According to the findings from the detailed study of the existing literature on learning styles, students' differences and their effects in the teaching styles, mentioned in section 2, the factors that influence in learning are numerous, internal and external, since the human learning is quite complex. However, even the interaction between them is unavoidable and diverse.

Another finding is that amongst internal factors we may refer to intelligence, temperament, health, motivation, personal values and so on, while among the external or surroundings ones a crucial importance is played by the learning environment in the broader sense like, for example, learning content, teacher's abilities, feedback, methods, models, books, movies, computer and so on.

Under the effect of internal factors, we respond to external effects in different quality. So, the learners have different preferences on information out looking and problem solving and from this perspective, according to the academics, they have different learning styles.

The commonsense conclusion from research in this area is that the teachers should be alert to detecting and responding to the differences in the ways that children learn (see Ebeling, 2000)

Matching the learning style of the student to the assignment is a marvelous way to get students engaged and allow them to experience success.( Nunley, F. Kathie, 1998)

Usually, the learning style does not reveal about a person's ability or intelligence, but it helps in understanding why some assignments seem simpler than others, why a learning surrounding motivates us more than another etc. 
For educators and teachers it is important to know: what the characteristic question of every type is, which educational situation is responsive to every type of student and how the teacher can be effective with every type of student.

"When planning and developing instructional material, strive for a balance of teaching styles to match the various learning styles". (Felder \& Soloman, 1992).

It is of great interest in the educational field to know Herman classification, which is connected to the brain dominant areas. Students are classified by terms related to preferences about specialized brain function. Therefore, logical, analytical, critical, structured, organized thinking, etc., are conducted by the left hemisphere; while the right hemisphere is thought to conduct emotive, intrapersonal, sensorial, kinesthetic, visual, holistic behaviors etc.

\section{Discussion}

\subsection{Why is information on learning styles interesting?}

What occurs when the learning styles of most of the classroom students do not fit the applied teaching style?

As teachers, we daily encounter inactive and gloomy students, students that do poorly at tests, discouraged, inattentive students etc., but rarely do we address the cause as badly chosen fitting.

Sternberg (1997), writes: "Many of the students we are consigning to the dust heaps of our classrooms have the abilities to succeed. It is we, not, they, who are failing. We are failing to recognize the variety of thinking and learning styles they bring to the classroom, and teaching them in ways that don't fit them well."

Can teachers suit teaching methods to every student's learning style? It is hard for a teacher to be able to tackle upon every student's individual needs. However, a teacher that is well-informed on students' learning styles may be able to do the best possible in particular teaching circumstances in order to suit the teaching method to the learning style in the main components.

Unfortunately, the traditional schools never take into consideration individual learning styles. As a consequence they tend to reward those students whose personal style matches the projected school methodology - and at the same time condemns those students that do not reach to match their rhythm (Lafrancois, G., 1997).

According to Dunn, Dunn and Perrin (1994), this situation is not fair; this is not an optimal learning situation. Judging from the studies, it is often mentioned, that even the students interested for the same subject, they have a lot of opportunities to organize the subject in various ways, and follow different manners to face with it (Pontecorvo, 1994).

\subsection{Learning styles vs. teaching styles}

Knowledge on the learning style variety, their categories, models and dimensions maybe might cause a kind of chaos in teachers. They need not be considered as aims in themselves. A teacher that is attentive to learning styles shows to be attentive to individual differences; a teacher and educator that is knowledgeable of cognitive style concepts might adopt the teaching strategies to enhance individual learning as well as help students to assume more responsibility on personal learning conditions.

It is very important for a teacher to know and not forget that every student has a unique personality and learning approach; only knowing this we may presume to be attentive to the learning style concept described by Lafrancois $\mathrm{G}$. (1997).

In a questionnaire (Reid, 1995) conducted with 18 teachers of English, teaching in the elementary schools of Elbasan, at the beginning of the school year on learning styles, it resulted that $54 \%$ of the students were mainly visual learners, $6 \%$ auditory learners and 30\% kinesthetic learners. These results helped the teachers to build their teaching mostly on demonstrations, pictures, writing on the blackboard, concrete objects, actions, etc. Here lies the importance of knowing students' learning styles on the part of the teachers to build their future lessons to be effective and successful (Tafani, V., (2003).

Steven Brookfield states: "The most important knowledge teachers need to do good work is a knowledge of how students are experiencing learning and perceiving their teacher's actions". A teacher who discerns how a personal preference affects students will try to create a learning environment that motivates all learner types. The identification of these types requires training for teachers and knowledge and usage of diagnosing and style-identifying questionnaires that are helpful for the process. If the theoretical preparation of teachers and educators about the learning style types and categories is easily achievable, it is important to emphasize that when it comes to practice, the identification of these styles in students requires particular attention. From classroom observations and interviews conducted with students in 
initial teacher education programs, the researcher has come to the conclusion that a teacher should find answers to these kind of questions:

- How to identify the learning styles of different personalities?

- How to link his/her teaching style to the students' learning styles?

- How to create and structure an environment suitable to all learner types?

- How does their learning style affect the way in which they learn?

But, how should this be achieved, that teacher be successful to find answers to these questions and to find the styles of individual learners. A teacher should know that:

- Students learn best and quicker if the teaching methods fit their favorite learning styles.

- The more learning improves, the more self-esteem, which has a great effect on learning, improves.

- Concentration attentiveness and students' motivation increase.

- Students that recognize their learning styles make better students.

- Teachers will better understand the differences between students.

- If a teacher's teaching style differs from many of his/her students' learning style, the teacher might need to make adjustments in the way of presenting material.

As mentioned in the methodology section, a questionnaire on learning styles was conducted with 60 teachers in three 9-year schools. In the data gathered from the answers to the questions in the uestionnaire, it is noticed that out of 60 participants, only 42 had some theoretical knowledge for the concept, learning style' and 18 of them didn't know anything about it.

For those teachers who had no knowledge of this concept, their answers were chaotic, as far as identification of students' typical behavior connected with these learning styles. As a consequence, they were not clear even in the answer of the question connected with the strategies that they should use in their classrooms, making the students able to learn in optimal manner according to their dominant style.

Below are the results of the teachers who had theoretical knowledge for learning styles. These teachers (42) are able to identify the preferred learning styles that their students have (according to the assignments given in various subjects), these influencing the way how to get information and how to analyze and interpret it. But, only 28 of them are able to use various strategies to give the opportunity to students to learn in well-structured learning situations. Some of them stressed that this happened even when they organized group work (with students of different styles), where each students felt comfortable in the part of the task he/she realized according to his/her style.

The other part, 14 teachers could identify their students according to their styles, but they couldn't manage the needed abilities to structurize the learning context with this aim. They write that depending on the subject they teach, they do their best that their students with visual learning style could have the context and environment favorable for them to use this sense through teaching materials as: mapa, graphs, etc. The students with auditory learning styles could listen to tapes, to the teacher and discuss on certain issues, and learn to listen one another. It is very important for this category of students to develop their listening skills. Students with kinesthetic learning styles are asked to write, to type, to draw diagrams, to paint, etc. Even in this uestionnaire it was noticed that most of the students have mostly visual learning style dominant.

\section{Conclusions and Recommendations}

Scholars recommend teachers to use direct observation and experience that consider learning styles while teaching. So the teachers should conduct questionnaires on learning styles of the learners at the beginning of each school year, and upon the answers the teachers plan their work that is going to be done the coming year, in the future, considering the students' learning style.

Literature clearly identifies that, regardless the variety of terms used for learning style, cognitive styles, defining the learner types, etc., we are convinced that teachers, educators and even learners should value it as one of the facilitating factors for a successful teaching process.

Information about teaching styles may and should be used as a guide to project learning experiences that either fit or misfit to learners' styles. However, as already mentioned, it is difficult for the teacher to adapt to every learning style, but a learning style portfolio is recommended (Moallem, 2001).

To overcome these problems, teachers should try to balance the instruction methods with the learning styles (which is contrary to the attempt of teaching every student according to his/her preference). If we achieve this balance, all students will be able to learn partially and in the way they prefer, even through a less favorite approach, but which will 
help them in being more effective in such situations. In any case, our aim is involving students as much as possible in the variety of situations offered within the classroom. It is always needed that while planning and developing the teaching material, the good teachers try to balance the teaching styles in order to adapt them to learning styles of their students.

It is important to know that abusing the learning styles concepts might bring about even undesirable consequences. This may occur, for ex., when styles are viewed as inherited fixed characteristics that limit the students' learning even in ways that do not comply to their styles. On the other hand, if a teacher uses and highly appreciates a particular learning style category, he/she may lose sensitivity to students' individual differences and changes that might occur in students throughout time. Also, even students who believe that they have a particular style and cannot change it, most probably will become indifferent in class and inattentive when the method used by the teacher does not suit to their style.

Good teaching does not only imply good communication of the content in a discipline; not only should a good teacher try the best to adapt his/her teaching style to the students' variety of styles, but also motivate students to continue learning and to optimally benefit in different teaching situations, teaching them the necessary abilities and strategies to make this happen. Individuals can learn through different ways and not only in the favorite style.

Learning styles, therefore, involve ways in which people learn. Each of us has a variety of learning styles. Some people may use a learning style lot less than other styles. Other people may use different styles in different environments. No suitable mixture is found and not even styles are fixed. The ability for less dominant styles may be developed as well as styles that have already been effectively used.

The conclusion reached by academics is quite interesting: according to which our learning abilities during schooling greatly affect our results, our education quality as well as the career choice; our learning abilities "at work" greatly affect our profession, our perspective, or a successful business; our personal learning abilities considerably affect even results in a professional training and not unimportant is the fact that we all want to be effective and have an everlasting good brain functioning. This may occur if we continually learn and mentally exercise.

Finally, the importance of teachers' and educators' preparation from this perspective is emphasized. It is a necessity for the teaching faculty curricula to be more sensitive to information and suggestions and recommendations about the learning styles and their importance, since these greatly affect the teachers' training quality. Worthwhile is teachers' organizing and participation in workshops about such topics which enable them to identify the students' learning styles and the approach of learning and teaching through these styles methods and techniques.

The study tries to prove the hypothesis that students with a learning style preference will learn more effectively if the learning process is guided according to their preferred style. Success in our life style much depends on the learning styles, which are very important to be known by educators. The paper comes to the conclusion that individual differences on learning styles affect a lot the teaching methodology of the teachers.

\section{References}

Boskolo, P., (1997): "Psicologia dell' aprendimento scolastico".Nuove Grafiche Artabano-Omegna, Milano. pp.118-116.

Felder, R. M. \& Silverman, L. K. (1988): "Learning Styles and Teaching Styles in Engineering Education“, Engr. Education, 78(7), 674-681. Felder\& Soloman. Retrieved from: http:// www.ncsu.edu/felder-public/lLSdir/styles.htm date 2/15/2007

Fleming, N.D. (2014): "VARK, a Guide to Learning Styles", http://www.vark-learn.com/english/page.asp?p=questionnaire, date 2/2/2015.

Keefe, J. W. (1979), (Ed.). Student Learning Styles: Diagnosing And Prescribing Programs. Reston, VA: National Association of Secondary School Principals. 1-17.

Heineman L.Peter (1995), "Cognitive versus learning style“. Retrieved from: http://www.personalityproject.org/others/heineman/-COG. HTM, date $4 / 15 / 2008$

Kolb (1974), Learning Styles, Retrieved from: http://www.businessballs.com/kolb learningstyles.htm, date 4/13/2008.

Lefrançois G. R., 1997: "Psicologia per insegnare", Armando Editore, Roma. pp. 266-268

McLeod, S. A. (2010). Kolb - Learning Styles. Retrieved from http://www.simply psychology.org/learning-kolb.html, date 2/3/2012

More, J. A. (1987): Native Indian Learning Styles: A review for researchers and Teachers. Journal of American Indian Education. Vol.27. N.1.

Myers - Briggs Test (MBTI), (2014), Retrieved from www.discoveryourpersonality.com date 5/3/2011

Nunley, F. Kathie (1998): Working with Styles. Retrieved from: http://help4teachers. com/learning styles.htm date 2/7/2012.

Pontecorvo, C. (1994). Psicologia dell Educazione. Giunti Lisciani Editori, Firenze. f.240

Reid, (1995); "The Learning Style Preferences of EFL Students", TESOL, Quarterly

Slavin, E.Robert. (2012). "Educational Psychology". Theory and Practice. Tenth Edition. Pearson.pp. 107.

Sternberg R.J. (1997): "Thinking Styles", pp. 16-17, Cambridge University Press, Cambridge.

Tafani, V. (2003): "Language Teaching \& Learning Methodology", Tiranë, shblu

Teaching Styles. Retrieved from: http://tt.its.psu.edu/suggestions/research/teaching-styles.shtml date 2/15/2007

Wall, J. (2004) The role of E-Learning - A Review.: Retrieved from http://www.multimedia-instruction.com , date 4/13/2008.

Verster, C. (2007). South Africa. Learning styles and teaching in http://www.teaching english.org.uk/try/othertry/other_activities.shtml, date $5 / 3 / 2011$. 